\title{
The future of fortifications in the city of Cadiz: opportunities and strategies for an urban regeneration
}

\author{
C. Rubio Bellido, P. Gallego Pérez \& R. Llácer Pantión \\ Department of Architectural Constructions II, University of Seville, Spain
}

\begin{abstract}
The pooled analysis of military heritage in the historic city of Cadiz is an approach to the understanding of a city mainly delimited by the sea and located in a strategic position. These conditions have contributed to the fact that this city has had a leading role throughout history. Cadiz has a patchwork culture with academic, traditional and overseas influences. As a result of the former, there are similarities with other coastal cities. The authors strive to perform a thorough analysis of the defensive fortifications of Cadiz under an overall criterion. In addition, a holistic understanding will enhance the historical and cultural value of the citadel of Cadiz with the aim of proposing these fortifications to be recognized as a World Heritage Site by UNESCO. This paper contributes to the preservation and the development of the fortified city of Cadiz. Moreover, it enhances its environmental regeneration and improvement of the cultural and tourism offer.
\end{abstract}

Keywords: military heritage, fort, fortifications, sustainable development.

\section{Introduction}

The city of Cadiz is in the south of Spain $\left(36^{\circ} 32^{\prime} \mathrm{N}, 6^{\circ} 18^{\prime} \mathrm{W}\right)$ and is largely surrounded by sea. When analysing the origin, formation and evolution of the city, the importance of its geographic and climatic conditions stand out. It is a separate, firmly closed, easily defended enclave, thanks to a calm sea in the bay, capable of providing a haven for entire fleets, and hostile waters to seaward, a sea blown by the Vendaval.

The land occupied by the historic centre today is a rocky platform in the shape of an irregular pentagon. It has been of great interest in history as a centre 
of commercial exchange and as a military enclave, two closely related activities. This area has seen various successive cultures such as the Phoenician, Greek, Carthaginian and Roman.

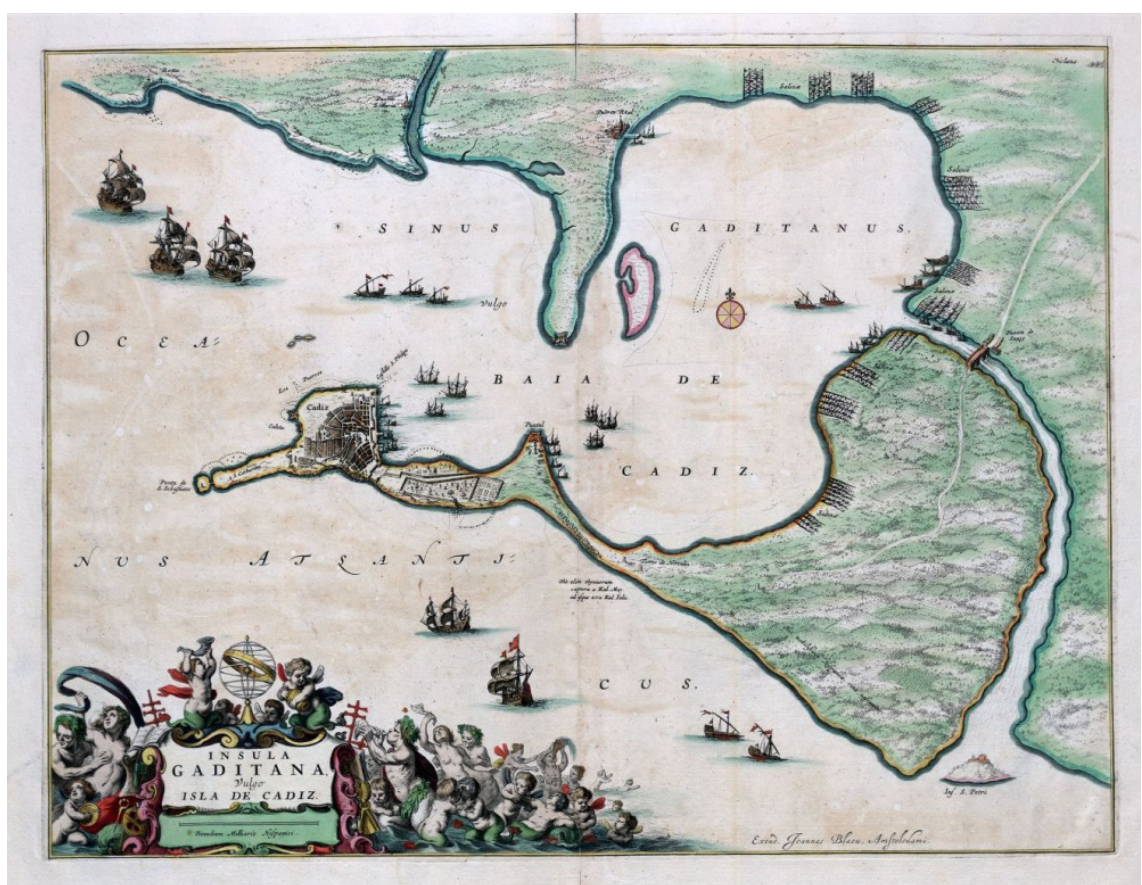

Figure 1: La Ínsula Gaditana (Isle of Cadiz) 1762. Joannes Blaeu. Virtual library of Andalusia. Ministry of Culture, Regional Government of Andalusia.

\section{Methodology}

\subsection{Selection of the study area}

The fortifications of the bay and the coasts of the provinces of Cadiz and Huelva have had great relevance throughout history from the military perspective. In the present document the research is focused on the whole of the walled complex with its different fortifications that enclose the historic city of Cadiz.

\subsection{Period studied}

The period studied covers from the mid-thirteenth century, when the first fortress was built, to the present day. The borders of the city have undergone numerous morphological alterations, which will be contextualized by the comparison of historical plans with those in the General Urban Distribution Plan [1]. 


\subsection{Field work and enhancement of the complex}

The evaluation of its present state will be made using several sources that create a matrix of very important data for an understanding and enhancement of the fortified city. Field visits to the different fortifications will assess the state of their conservation and whether they accommodate some current use. These will be complemented with the study of the current protection of these constructions according to the effective legislation regarding Heritage and its comparison with the Andalusian Defensive Architecture Plan.

\subsection{Action strategies}

After prior in-depth analysis, different action strategies will be formulated based on the historical study, degree of conservation, present use and relationships of the different fortifications with the urban space.

\subsection{Evaluation as World Heritage}

The complex of the various fortifications that have surrounded the historic city for centuries was frequently used as a model by Spanish engineers who extrapolated its design to various Latin American cities, because Cadiz, post 1717, housed the Spanish headquarters of the Casa de Contratación (House of Commerce) which controlled the commerce with the Americas. The fortifications of these cities are World Heritage sites [2], designed by the Spanish crown and with formal contents resembling the fortifications of Cadiz.

\section{Military heritage in Cadiz}

\subsection{Genesis of the city and the first walled enclosure}

The city of Cadiz owes its name to the fortifications, because etymologically Gador, Gader, Gadir or Gades mean a closed or walled place. According to recent archaeological findings, there were already defensive systems of considerable significance in Roman times.

King Alfonso X conquered the city in 1262, considering it a bridge towards Africa. The city, which was limited to a few settlements, was remodelled and equipped with walls on three of its sides, with the ocean being on its fourth. These walls, partially conserved, have three gates that are currently preserved: Arco de los Blancos, Arco del Pópulo and Arco de la Rosa. The cathedral was built within the walls, as were various buildings over old constructions.

\subsection{The walled city - XVI to the XIX centuries}

In 1578 , because of the potential of the city due to its strategic situation, and after various insignificant attacks, King Felipe II commanded the fortification and defence of the city to be designed, which was undertaken by the Italian expert Captain Fratín. 
In 1587 the assault by the English Admiral, Francis Drake, had little repercussion on the partially fortified city. A small bastion named Santa Catalina had been constructed, with the entire area up to the bay being delimited by a wall, Figure 2, which ran from the Puerta de Tierra (left) to the fort of San Felipe (right) [3]. At this point in history the relationship of the population with these walls is indicated by the words of Agustín Horozco about this sector of the city. "To one side on the bay there is a small bastion with artillery that serves as a viewpoint and rest area for those walking there" [4].

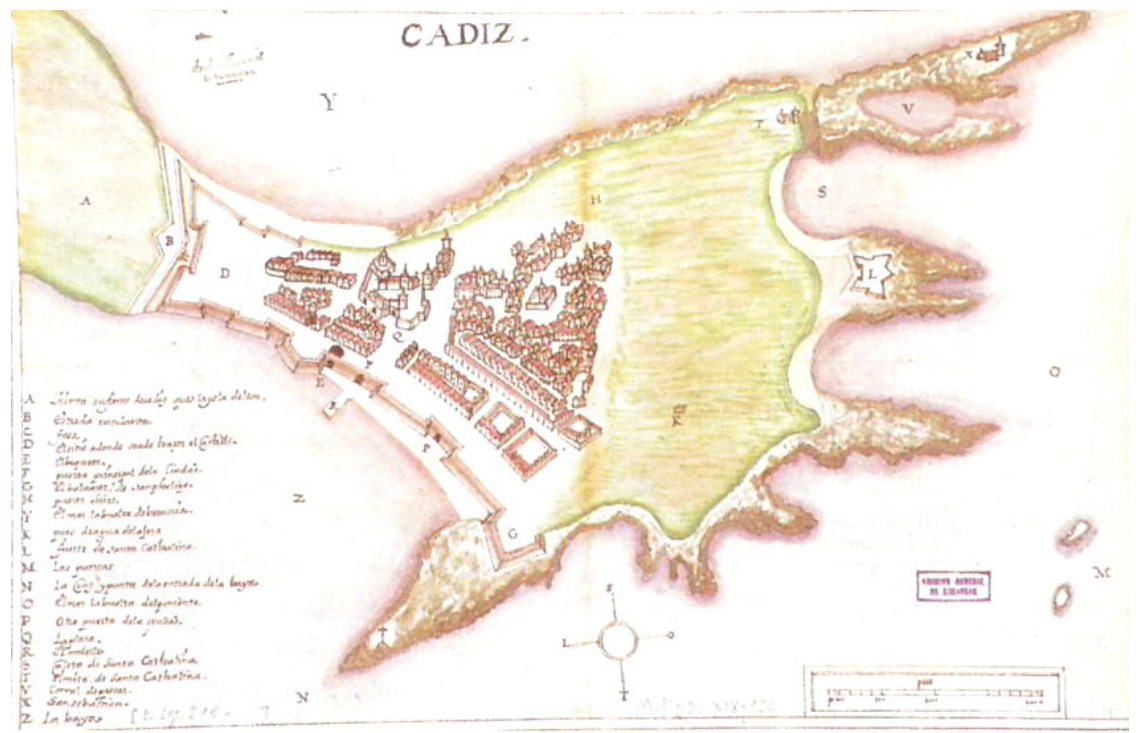

Figure 2: $\quad$ Cadiz 1609. General Archive of Simancas.

In 1596, the English carried out a large invasion and sacking, under the command of the 2nd Earl of Essex [5]. King Felipe II asked for information to decide whether to fortify or to leave Cadiz, and the Mayor, Antonio Ossorio, showed the advantages of fortifying the city. This was the first time in history that colonizing the edges of the city had been considered in order to protect it, recognizing it as a fortified complex.

There were numerous attacks on the city during the XVII century due to it being a strategically important point for the maritime traffic with America and the control of the Straits of Gibraltar. This was made clear by King Felipe IV in 1660: "Cadiz was the most importance garrison in this Monarchy, which is why enemies had their eye on invading it" [6].

Various fortifications were already constructed at this time, under the direction of the engineer, Cristóbal de Rojas. In 1639, the defensive installations began for the Puerta de Tierra, the only land access to the city. The fortification of the city adopted the figure of a pentagon responding to the idea of using the main natural projections as the strong points. A strong wall served as protection against the onslaughts of the sea, with bastions and wide platforms for artillery 
batteries according to the influences of Marshal Vauban, and which served during the XVII and XVIII centuries to repel the attacks of the English squadrons.

In 1717, Cadiz was proposed as the centre for the trading of goods and ideas with the new world, as it now hosted the House of Commerce which controlled trade with the Americas. It is from that time that the city lived its golden age. A flourishing commerce arose under the protection of the military defence [7]. Fortifications were renewed and projected into the bay and continued reinforcing the city. The XVIII century saw the end of the construction stage of the fortifications when they were consolidated and strengthened.

In 1786, Luis Huet, Director General of Engineers, began his management in Cadiz, undertaking works on the wall as well as making a list of all the fortifications with all its defects, writing up a plan of defence of the garrison and bay of Cadiz.

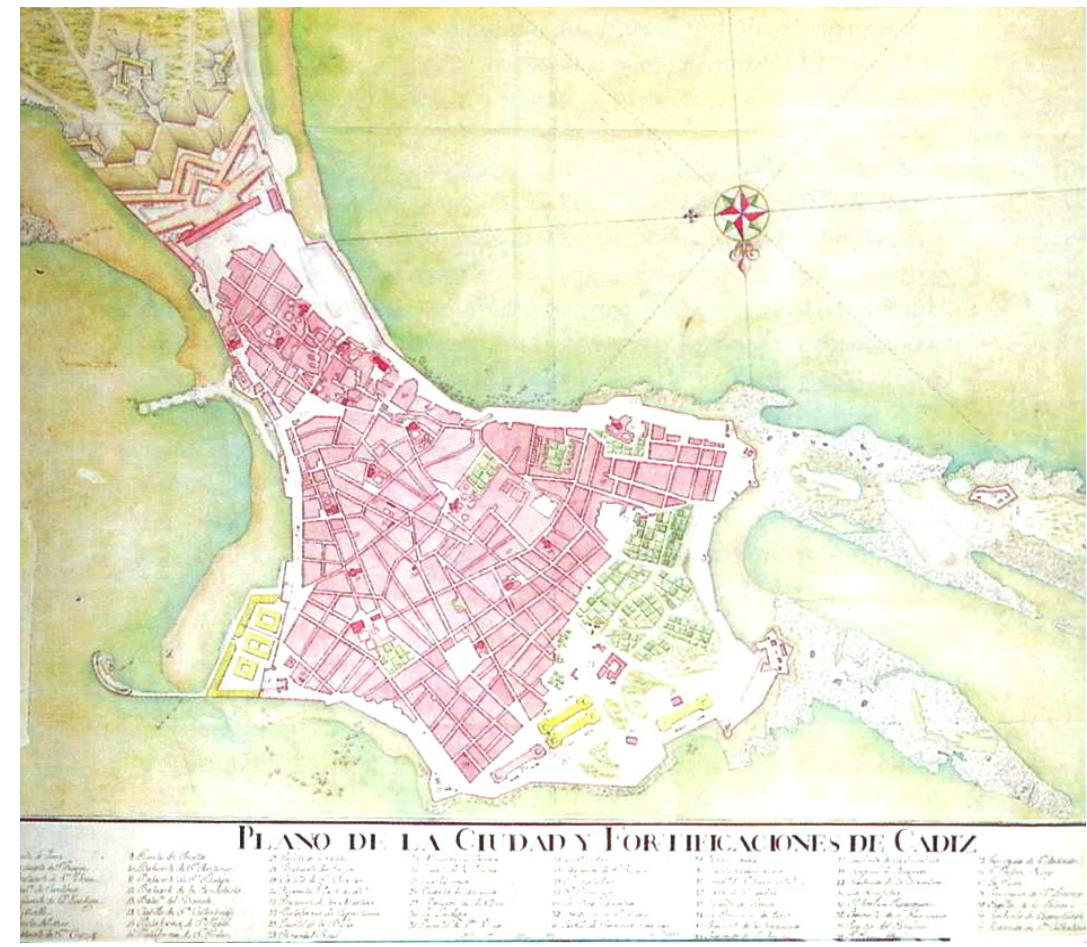

Figure 3: Plan of the city and the fortifications of Cadiz. Antonio Doncel. 1760. Army Geographic Service.

During the Peninsular War with France, Cadiz played a major role thanks to its fortified complex. It was under siege from 1810 to 1812 , and was the only city not to be invaded, and hosted the National legislative body, the Cortes, when 
it wrote the first Spanish Constitution, this current year (2012) marking its bicentenary.

As the XIX century advanced new infrastructures began to be introduced into the city such as the railway, the public lighting system and the water supply. At the end of that century, when the harbour works were begun, Cadiz returned to having an important role as a base for embarking Spanish troops for the war of Cuba, again showing its possibilities as a military city.

\section{Enhancement of the fortified complex}

\subsection{The present state of the fortifications}

As can be seen in Figure 4, Cadiz preserves numerous examples of fortifications that mark out its perimeter although, in some cases, the route is buried or missing. This plan is the result of the analysis of historical mapping, urban/archaeological data and the data collected from field work.

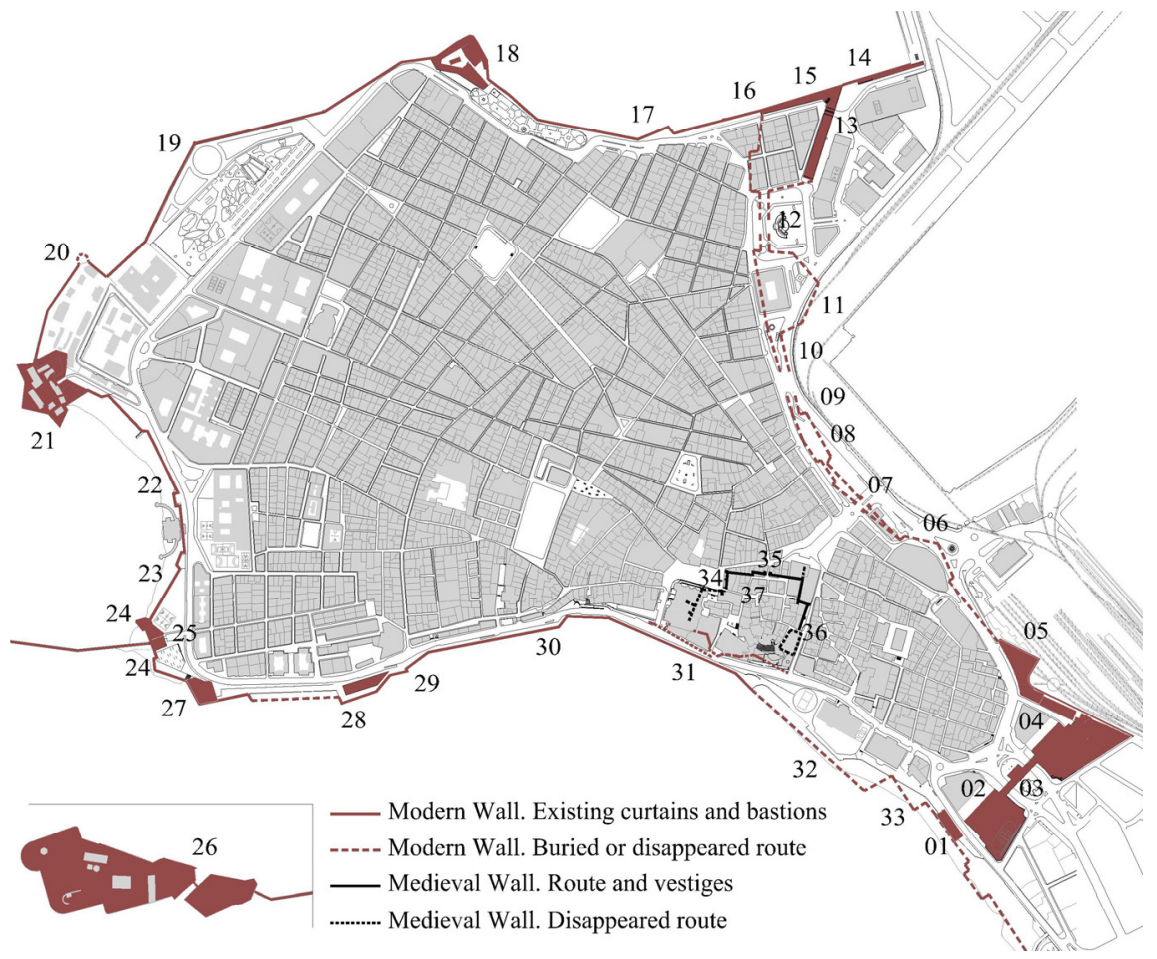

Figure 4: Plan of the fortifications of the city at the present time. Own production.

Currently, the understanding of the defensive system of Cadiz as a fortified complex goes un-noticed and its maintenance, the military function already lost, is insufficient. In specific cases, the implementation of new uses in these spaces 
Table 1: $\quad$ List of Fortifications. Own production.

\begin{tabular}{|c|c|c|c|c|}
\hline $\mathrm{N}^{\mathrm{o}}$ & FORTIFICATION & YEAR & STATE & USE \\
\hline 01 & Bóvedas de San Roque & 1594 & Acceptable & Cultural \\
\hline 02 & $\begin{array}{l}\text { Semi-bastion, barracks and } \\
\text { buildings of San Roque }\end{array}$ & 1594 & Acceptable & $\begin{array}{c}\text { Cultural } \\
\text { Comercial }\end{array}$ \\
\hline 03 & Frente de Puerta de Tierra & 1594 & Acceptable & Cultural \\
\hline 04 & $\begin{array}{l}\text { Semi-bastion, barracks and } \\
\text { buildings of Santa Elena }\end{array}$ & 1775 & Acceptable & Cultural \\
\hline 05 & Baluarte de Santiago & 1594 & Deficient & Parking \\
\hline 06 & Baluarte de los Negros & 1775 & Disappeared & - \\
\hline 07 & Puerta del Mar & 1594 & Disappeared & - \\
\hline 08 & Baluarte de Santa Cruz & 1594 & Disappeared & - \\
\hline 09 & Muralla Real & 1594 & Disappeared & - \\
\hline 10 & Puerta de San Antonio & 1594 & Disappeared & - \\
\hline 11 & Baluarte de San Antonio & 1594 & Disappeared & - \\
\hline 12 & Puerta de San Carlos & 1594 & Disappeared & - \\
\hline 13 & Baluarte de San Carlos & 1594 & Acceptable & Commercial \\
\hline 14 & Baluarte de San Felipe & 1732 & Acceptable & Commercial \\
\hline 15 & Baluarte de San Felipe alto & 1775 & Acceptable & Commercial \\
\hline 16 & Walls of San Carlos & 1594 & Acceptable & Without use \\
\hline 17 & Rediente de la Alameda & 1672 & Sufficient & Without use \\
\hline 18 & Baluarte de la Candelaria & 1672 & Acceptable & Cultural \\
\hline 19 & Baluarte de la Bomba & 1672 & Deficient & Parking \\
\hline 20 & Baluarte de Bonete & 1672 & Disappeared & Without use \\
\hline 21 & Castillo de Santa Catalina & 1598 & Acceptable & Cultural \\
\hline 22 & Plataforma de San Pedro & 1672 & Deficient & Without use \\
\hline 23 & Plataforma de San Pablo & 1672 & Deficient & Without use \\
\hline 24 & Baluarte de Orejón & 1672 & Deficient & Without use \\
\hline 25 & Puerta Caleta & 1672 & Deficient & Without use \\
\hline 26 & Castillo de San Sebastián & 1457 & Deficient & Without use \\
\hline 27 & Baluarte de los Mártires & 1672 & Sufficient & Commercial \\
\hline 28 & $\begin{array}{l}\text { Bastion and platform of los } \\
\text { Capuchinos }\end{array}$ & 1672 & Sufficient & Social \\
\hline 29 & Plataforma de Puerto Chico & 1570 & Sufficient & Without use \\
\hline 30 & Flanco de San Rafael & 1672 & Sufficient & Without use \\
\hline 31 & $\begin{array}{l}\text { Walls of San Felipe and San } \\
\text { Miguel (Murallas Vendaval) }\end{array}$ & 1672 & Sufficient & Without use \\
\hline 32 & Flanco de San Nicolás & 1672 & Disappeared & - \\
\hline 33 & Flanco de Matadero & 1672 & Disappeared & - \\
\hline 34 & Arco de la Rosa & 1262 & Acceptable & Without use \\
\hline 35 & Arco del Pópulo & 1262 & Acceptable & Without use \\
\hline 36 & Arco de los Blancos & 1262 & Acceptable & Without use \\
\hline 37 & Medieval Wall & 1262 & Deficient & Without use \\
\hline
\end{tabular}


has been carried out, contributing to their preservation but, in general, it suffers from the lack of a comprehensive project that interrelates all the pieces, by means of a global understanding and a detailed enhancement.

\section{Strategies and opportunities}

All the fortifications of Cadiz, with a very high heritage value as a whole and studied in-depth in their urban context [8], have the potential to open this city to the world by means of a series of strategies which promote their sustainable development.

\subsection{Cultural use}

The large infrastructure is proposed for cultural use associated with the city. Some are currently used in this way, although it would be advisable to promote them with the objective of a greater influx of the public, both local and tourist. Thus the Castillo de Santa Catalina, the Castillo de San Sebastián and the Baluarte de la Candelaria, are spaces that could be great centres of attraction for citizens and tourists alike.

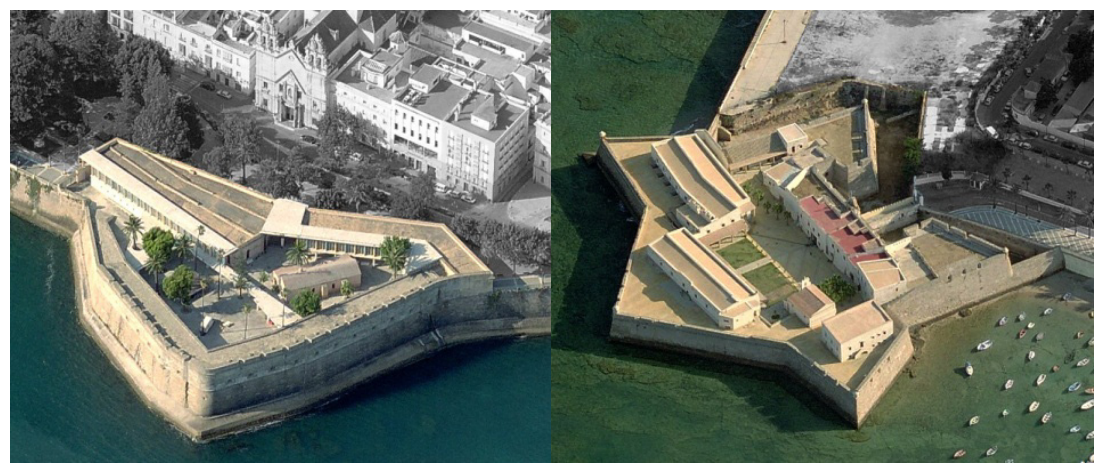

Figure 5: Aerial view of the Baluarte de la Candelaria and Castillo de Santa Catalina.

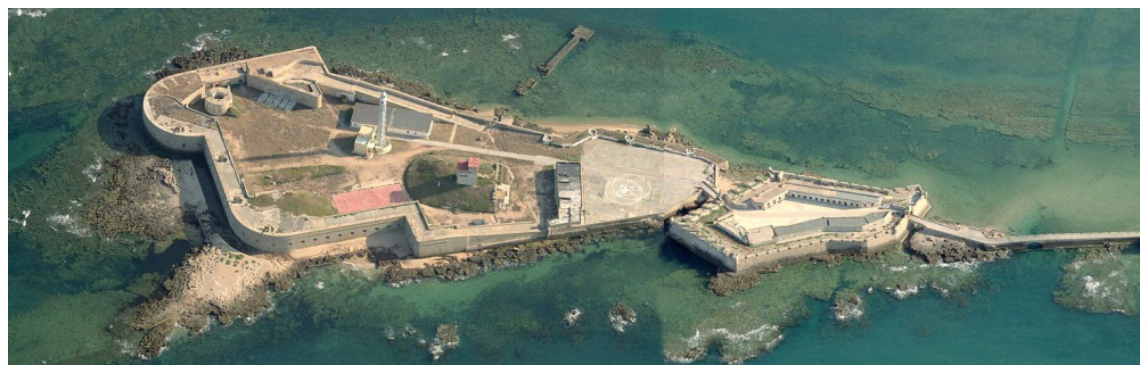

Figure 6: Aerial view of the Castillo de San Sebastián. 


\subsection{Walking itineraries}

The great curtains of the walls that surround almost the whole of the city, are spaces that have been used from antiquity for strolling and contact with the sea, which contributes that great luminosity so often mentioned in literary descriptions, and is due to the Albedo effect, or whiteness of the light, produced by sunlight reflected from the water surface.

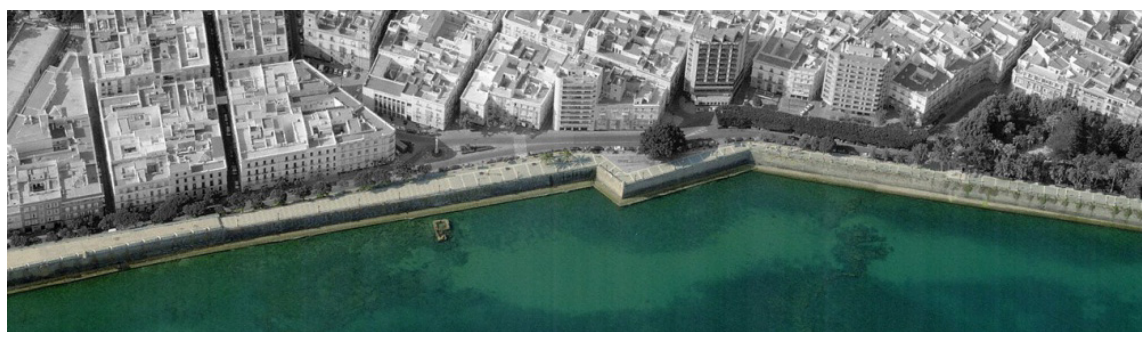

Figure 7: Aerial view of the Alameda Apodaca and Muralla de San Carlos.

\subsection{Points of interest and green spaces}

There are sites of numerous platforms or bastions, where only the contour and widening of the wall remain. These places, which are repeated throughout the curtains of the wall, are rest areas and viewpoints that allow an appreciation of the urban landscape of the city [9]. There are also bordering gardens that can be points of relaxation and reflection, as are those of the Parque Genovés and the Alameda Apodaca.

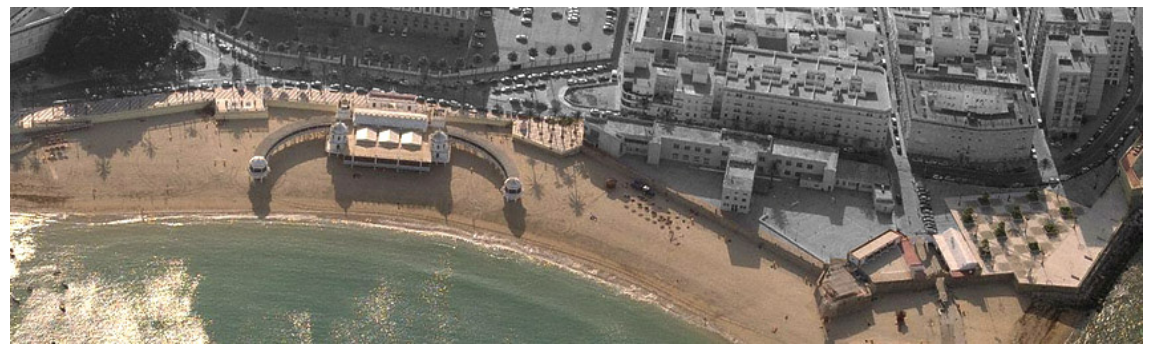

Figure 8: Aerial view of the area around La Caleta.

\subsection{Recovery of the vestiges of the wall}

At the beginning of the XX century the wall in the section next to the expanding harbour area was demolished, with the consequent disappearance of the Muralla Real and the gates adjoining the bay. The recovery of these vestiges will enhance them and the heritage of the city in tourist routes, as well as the recovery of the natural entrance to the city; the Puertas del Mar. 

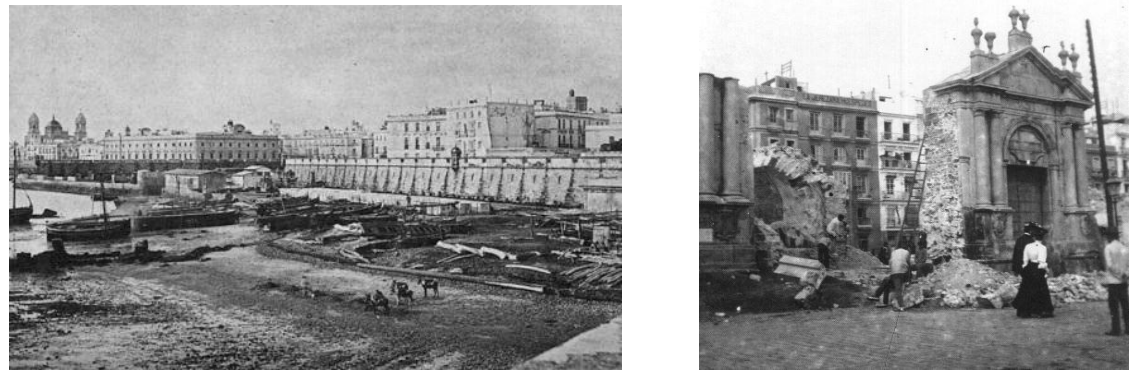

Figure 9: $\quad$ Muralla Real and demolition of the Puertas del Mar, 1906.

\subsection{Commercial and third party use}

Certain spaces, which are integrated into the urban fabric, are used as commercial premises and craftsmen's workshops to promote local commerce. Thus the walls of San Carlos and the semi-bastion of San Felipe, as well as the Bastions of San Roque, Santa Elena and los Mártires are fortifications which are

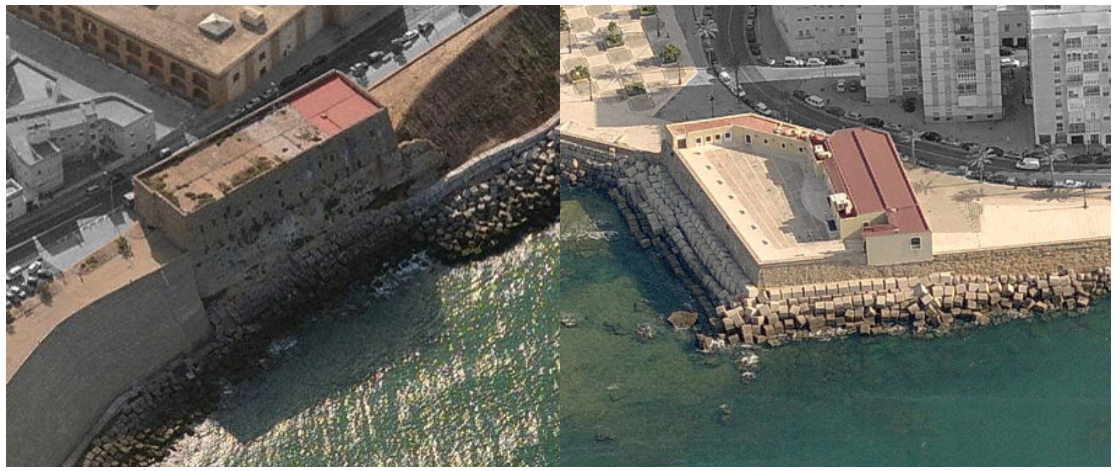

Figure 10: Bastion of San Roque and Bastion of los Mártires.

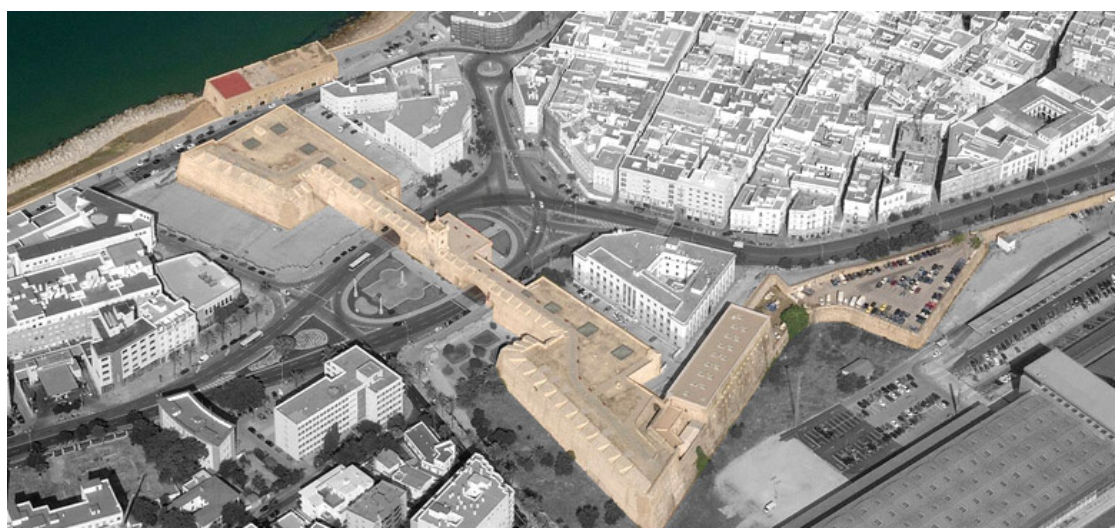

Figure 11: Current surroundings of the Puerta de Tierra. 
clear examples of these types of uses, implemented from their beginnings and which at present have only been partially developed, generating an image of marginality.

Some constructions have been attached to and appropriated the areas bordering the fortifications. The relocation of uses and the demolition of buildings that obscure the fortified complex are proposed.

The objective is the regeneration of urban spaces, to return it to its original state. Thus the rearrangement of the surroundings of, for example, the Puerta de Tierra, La Caleta or the Murallas de San Carlos, would be candidates for this remodelling.

\subsection{Recognition of the perimeter. maritime itinerary}

The reintroduction and promotion of old maritime itineraries, now disappeared, is proposed. With this measure the urban border will be recognized from the maritime space, transferring us to the vista of the travellers who approached the city from seaward.

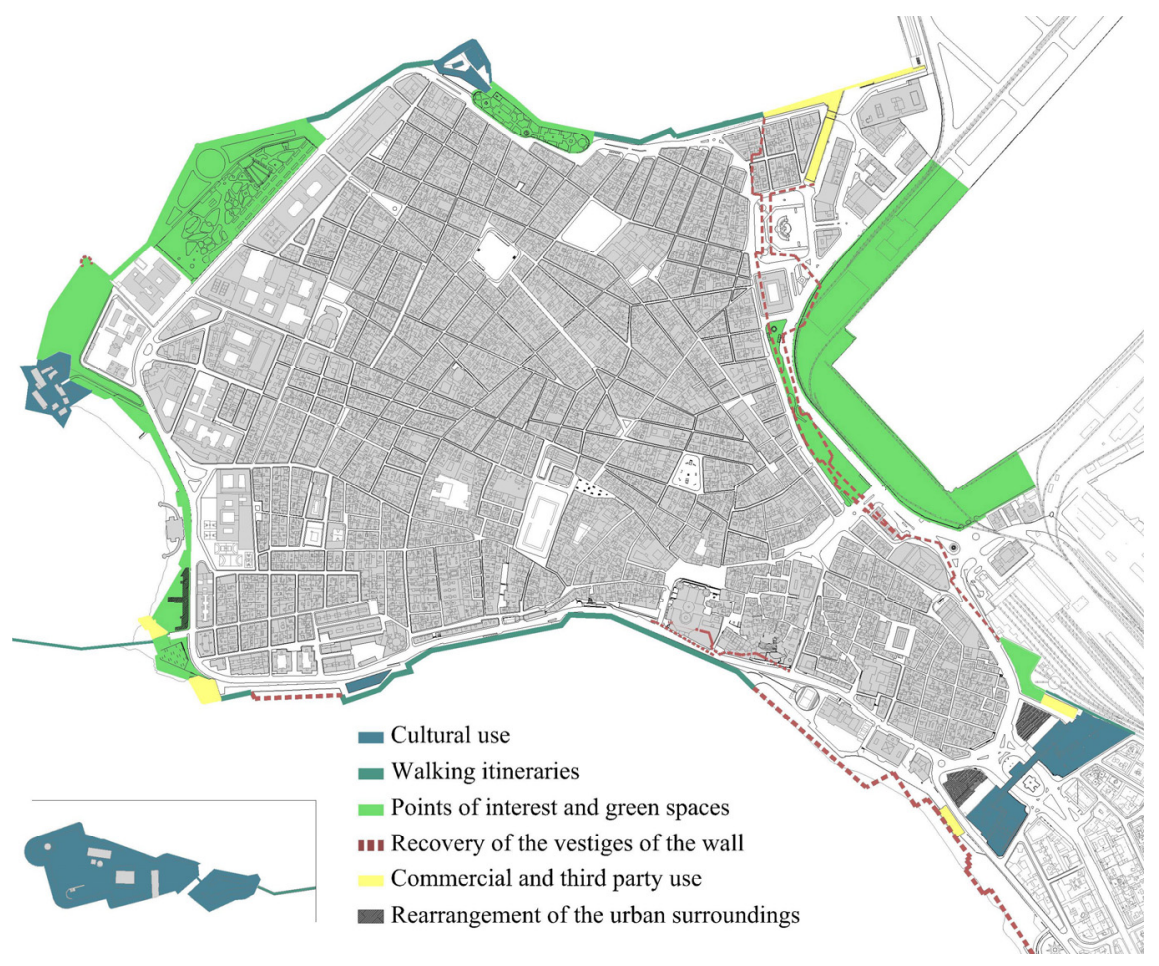

Figure 12: Plan of the different strategies proposed. Own production. 


\section{The complex of fortifications as World Heritage}

The recognition by UNESCO of the fortified complex of the city as a World Heritage site is an engine to carry out all these opportunities and strategies and optimize the value of this complex. The objective of the programme is to catalogue, preserve and bring to light sites of exceptional cultural or natural importance to the common heritage of humanity. Under certain conditions, the conservation of the mentioned sites could attract funding from the World Heritage Fund.

From all that has been expressed above, the authors believe that the fortification complex of Cadiz has an outstanding universal value, which is the main criterion considered by UNESCO, in addition to satisfying many others. It has been a place that has born witness to the exchange of human values throughout history, the fortifications of the city being an architectural model that has been exported to, and developed in, various other countries. In addition, it offers an architectural complex that illustrates a significant stage of history and is an eminent example of a tradition of human settlement, with the use of the sea as a human interaction with the environment. Finally, the fortifications complex is an area of exceptional natural beauty and aesthetic importance. For all these criteria, in agreement with UNESCO, the fortifications complex of the city of Cadiz, in our opinion, has sufficient values for its listing as a World Heritage Site.

\section{Conclusions}

The authors present the current work for the revitalization of the fortified complex of the city of Cadiz as part of wider research. This is another document to contribute to the evaluation by the World Conservation Union and the International Council on Monuments and Sites (ICOMOS), for its future processing as a World Heritage Site. The proposed strategies and intervention opportunities, acting globally on the whole fortified complex, will strengthen the interaction and understanding of the different constructions that border the city. "These fortifications are not masses of dead stone. They had life and they are part of our history. And in her, multi-millenarian Cadiz, will always be signified the spirit of maritime venture, commerce, and the exchange of ideas and culture with the most distant peoples..." [1].

\section{References}

[1] Plan General de Ordenación Urbana de Cádiz.www.cadiz.es/ PGOU 2011.cadiz

[2] Lista Patrimonio de la Humanidad por la UNESCO.whc.unesco.org/en/list

[3] Perez de Sevilla y Ayala, V., La artillería española en el Sitio de Cádiz, Instituto provincial de estudios gaditanos, Cádiz, 1978.

[4] Horozco, A. Discurso de la Fundación y Antigüedades de Cádiz. Universidad de Cádiz, Servicio de Publicaciones, Cádiz, 2001. 
[5] Abreu, P. Historia del saqueo de Cádiz por los ingleses en 1596, Universidad de Cádiz, Servicio de Publicaciones, Cádiz, 1996.

[6] Castro, A. Sobre el recinto de la Ciudad y a quién pertenece. Cádiz, 1862.

[7] Jiménez Mata, J. \& Malo de Molina, J., Guía de arquitectura de Cádiz, Consejería de Obras Públicas y Transportes, Sevilla, 1995.

[8] Llácer Pantión, R. Cádiz. Caracterización de los bordes de la ciudad histórica. Universidad de Sevilla, 2008.

[9] Llácer Pantión, R. Potencialidad de los paisajes de bordes marítimos urbanos. El caso del casco antiguo de Cádiz, Coloquio Internacional paisajes de la vida cotidiana: Perpignan y Gerona, 2011.

[10] Calderón Quijano, J.A. Las defensas del Golfo de Cádiz en la Edad Moderna, Escuela de Estudios Hispano-Americanos, Sevilla, 1976. 